\title{
Prevalence of Iron Deficiency anemia in Obese Children in Taif Area - Saudi Arabia
}

\author{
Malak Eidha Aloufi, Nejood Metaeb Aljaed, Rawan Abdulrahman Aloufi, Suzan Abdullah \\ Jafri, Sumayyah Abdullah Jafri, Manal Ahmed EInashar. \\ Department of pediatrics, Faculty of Medicine, Taif University \\ Corresponding author: Malak Eidha Aloufi, E-mail: Malak.aloufi@ hotmail.com, Tel: +966581313887
}

\begin{abstract}
Background: The growing global health problem is obesity which has increased dramatically in recent years. The prevalence of obesity continues to rise in developed and developing countries, Poor iron status are affecting millions of people worldwide. Iron deficiency is the first nutrient deficiency all over the world and both obesity and iron deficiency may lead to adverse health issues. In 2013, an estimated 42 million children aged under 5 years $(6.3 \%)$ were overweight, an increase from around 5\% in 2000 to $6 \%$ in 2010 and 6.3\% in 2013, with the highest rates of increase being observed in Africa and Asia. Rapid changes from traditional to new diets, which contain large amounts of fat, sugar and oil is one of the major causes of obesity. Obesity has been associated with higher rates of death driven by co morbidities. According to the recent researches, the rate of obesity is significantly high in Saudi Arabia, and expected to increase in future.

Aim of the study: To evaluate the association between the obesity and iron deficiency anemia among children in Al-Taif Region, Kingdom of Saudi Arabia and to increase the awareness about the hazards of obesity on the general health. Method: A cross sectional study design. A structured questionnaire was designed to obtain the necessary information from a convenient sample of 200 child aging from (512 years) attending the pediatric outpatient clinics of pediatric hospital in Taif region - Saudi Arabia from August till November 2016. Information about weight, height, Body Mass Index (BMI), Hemoglobin levels and the serum iron. The assessment of obesity with BMI index using the CDC2000 reference percentile was divided into four categories5th, 50th, 85th and 95th, namely; underweight, normal, overweight and obese respectively. Iron Deficiency was defined as Transferrin Saturation lower than $16 \%$ and Iron deficiency anemia was defined as Transferrin Saturation lower than $16 \%$ and hemoglobin $(\mathrm{Hb})$ concentration lower than $12 \mathrm{~g} / \mathrm{l}$ or $12 \mathrm{mg} / \mathrm{dl}$ for children. Results: This study shows negative significant correlation between hemoglobin level with the BMI ( $\mathrm{r}-0.429 \mathrm{p}$ value 0.017 ) delayed weaning \& no iron supplements ( $\mathrm{r}-0.338 \mathrm{p}$ value 0.023 ), bad food habits ( $\mathrm{r}-0.309 \mathrm{p}$ value 0.012 ) and warm disease, ( $\mathrm{r}--0.406 \mathrm{p}$ value 0.028 ), suffering from poor food absorption disease ( $\mathrm{r}$ $0.266 \mathrm{p}$ value 0.033 ) and chronic diarrhea ( $\mathrm{r}-0.311 \mathrm{p}$ value 0.011$)$. The prevalence of anemia among the study group shows $60 \%$ of its group are suffering from high BMI $79.2 \%$ of them suffering from IDA, while $20.8 \%$ are healthy. $40 \%$ of study group are with normal BMI $21.25 \%$ of them are suffering from anemia while $63 \%$ are healthy. Conclusions: Hepcidin plays a central role in the anemia of chronic disease and Hepcidin overproduction even in mild inflammatory disorder as obesity may explain the association of poor iron status with obesity. IL6 and Leptin may be part of the axis that links obesity, inflammation, and Hepcidin with poor iron status. This study suggests that the higher levels of total obesity should be taken into account when assessing the children's body iron status and should be treated before providing dietary recommendations to correct anemia.
\end{abstract}

Keywords: Iron Deficiency anemia, Obese Children, hemoglobin level, Hepcidin.

\section{Introduction:}

The growing global health problem is obesity which has increased dramatically in recent years ${ }^{1}$. The prevalence of obesity continues to rise in developed and developing countries, Poor iron status are affecting millions of people worldwide. Iron deficiency is the first nutrient deficiency all over the world and both obesity and iron deficiency may lead to adverse health issues ${ }^{2}$.

In 2013, an estimated 42 million children aged under 5 years $(6.3 \%)$ were overweight, an increase from around 5\% in 2000 to $6 \%$ in 2010 and $6.3 \%$ in 2013, with the highest rates of increase being observed in Africa and $\mathrm{Asia}^{3}$. 
One of the major causes of obesity is the rapid changes from traditional to new diets, which contain large amounts of fat, sugar and oil. In addition to the environmental factors such as marketing, advertising, increasing portion sizes, accessibility and availability of calorie dense foods and increased automation, all of which have contributed to increased energy intake and reduced energy expenditure which can lead to overweight and obesity among children and adolescents ${ }^{4}$. Obesity has been associated with higher rates of death driven by comorbidities such as type 2 diabetes mellitus (T2DM), dyslipidemia, hypertension, obstructive sleep apnea (OSA), certain types of cancer, steatohepatitis, gastroesophageal reflux, arthritis, polycystic ovary syndrome (PCOS), and infertility. Obesity has been associated also with increasing the risk of musculoskeletal pain and osteoarthritis ${ }^{2}$.

Due to the poor diet caused by foods high in calorie but low in nutrients consumption, obese children are susceptible not only to complications such as fatique but also to a variety of micronutrient deficiencies ${ }^{5}$.

Anemia can cause many adverse effects on child health, as delayed psychomotor development, impaired cognitive function, IQ loss and increased susceptibility to lead toxicity. Correction of iron deficiency at this age group enhances children's learning potential in schools, increases their fitness and work capacity. In addition improvement of girls iron status may help to prevent anemia during the reproductive years ${ }^{6}$.

According to the research paper in Saudi Arabia findings, the rate of obesity is significantly high in the country, and expected to increase in future ${ }^{7}$.

Overweight and obesity act as low-grade inflammatory diseases, can lead to transformation of iron metabolism, tissue iron overload, mobility decline and reduce the breakdown of myoglobin and a decrease in serum iron for hematopoiesis ${ }^{8}$.

Adipose tissue defined as an endocrine organ that can contribute to the inflammatory process by secreting proinflammatory cytokines named adipokines, and the resulted inflammatory state may have an important pathogenic role in some obesity-related comorbidities ${ }^{9}$.

Hepcidin which is secreted by hepatocytes, circulate in blood plasma and excreted in urine, its expression in the liver is increased by inflammatory mediators which lead to iron deregulation. Hepcidin may be linked to other adipokines commonly elevated in obesity including Leptin ${ }^{10}$.

Aim of the study:

To evaluate the association between the obesity and iron deficiency anemia among children in Al-Taif Region Kingdom of Saudi Arabia and to increase the awareness about the hazards of obesity on the general health.

\section{Methods:}

Sample Collection:

A cross sectional study design. A structured questionnaire was designed to obtain the necessary information from a convenient sample of 200 children aging from (5-12 years) attending the pediatric outpatient clinics of pediatric hospital in Taif region - Saudi Arabia from August till November 2016.

Information about weight, height was recorded using zero calibrated instruments. The anthropometric assessment included weight, height. Weight was measured with the use of digital scale and height was measured with the use of SECA height gauge with an accuracy of $0.5 \mathrm{~cm}$ in a standing position without shoes and keeping the shoulders in a relaxed position. Body Mass Index (BMI) was calculated from weight (kg) / (height (m)) ${ }^{2}$. BMI was considered as a criterion to assess total obesity. The assessment of obesity with BMI index using the CDC2000 reference percentile was divided into four categories: 5th, 50th, 85th and 95th, namely; underweight, normal, overweight and obese respectively ${ }^{11}$.

Hemoglobin levels, the serum iron and seum iron saturation were obtained from patient file from pediatric clinic of Pediatric Hospital Al-Taif Region Saudi Arabia. Iron Deficiency (ID) and Iron Deficiency anemia (IDA) were defined according to WHO criteria. ID was defined as Transferrin Saturation (TS) lower than $16 \%$ and IDA was defined as TS lower than $16 \%$ and hemoglobin $(\mathrm{Hb})$ concentration lower than $12 \mathrm{~g} / \mathrm{l}$ or $12 \mathrm{mg} / \mathrm{dl}$ for children ${ }^{11}$.

\section{Exclusion criteria:}

The exclusion criteria were any disorder such as liver disease, cardiac disease, chronic GI disease, heart disease, chronic hematologic disorders except iron deficiency (with or without anemia).

Statistical analysis:

Data were analyzed using Statistical Program for Social Science (SPSS) version 20.0. Quantitative 
data were expressed as mean \pm standard deviation (SD). Qualitative data were expressed as frequency and percentage. The following tests were done: Spearman's rank correlation coefficient (rs) was used to assess the degree of association between two sets of variables if one or both of them was skewed.

- Probability (P-value)

- P-value $\leq 0.05$ was considered significant.

- P-value $\leq 0.001$ was considered as highly significant.

- P-value >0.05 was considered insignificant.

\section{RESULTS}

Table (1): Household level distribution of the study group.

\begin{tabular}{|c|c|c|}
\hline Household level & $\begin{array}{l}\text { No. } \\
{[\mathrm{N}=200]}\end{array}$ & $\%$ \\
\hline Residence & & \\
\hline Urban & 168 & 84 \\
\hline Rural & 32 & 16 \\
\hline $\begin{array}{l}\text { Number of children in the } \\
\text { family }\end{array}$ & \multicolumn{2}{|c|}{$1-10[3.92 \pm 2.12]$} \\
\hline Educational level of the mother & & \\
\hline Illiterate & 4 & 2 \\
\hline Primary & 44 & 22 \\
\hline Average & 90 & 45 \\
\hline High & 62 & 31 \\
\hline Educational level of the father & & \\
\hline Illiterate & 8 & 4 \\
\hline Primary & 48 & 24 \\
\hline Average & 54 & 27 \\
\hline High & 90 & 45 \\
\hline Job of father & & \\
\hline Not worker & 70 & 35 \\
\hline Worker & 130 & 65 \\
\hline Job of Mother & & \\
\hline Not worker & 60 & 30 \\
\hline Worker & 54 & 27 \\
\hline Housewife & 86 & 43 \\
\hline $\begin{array}{l}\text { Nutrition distribution of the study } \\
\text { group }\end{array}$ & & \\
\hline Breast feeding & & \\
\hline Breast feeding & 0 & 0 \\
\hline Feeding industrial & 200 & $\begin{array}{l}10 \\
0\end{array}$ \\
\hline $\begin{array}{l}\text { Iron supplements } \\
\text { No Iron supplements } \\
\text { Iron supplements }\end{array}$ & $\begin{array}{l}142 \\
58\end{array}$ & $\begin{array}{l}71 \\
29\end{array}$ \\
\hline
\end{tabular}

Table (1) shows that $84 \%$ of study group are from Urban area and $16 \%$ are from Rural area. $31 \%$ of the mother of our study group are highly educational, $45 \%$ are average educated, $22 \%$ are primary educated and $2 \%$ are are Illiterate while $45 \%$ of the father of study group are highly educated, $27 \%$ are average educated level, $24 \%$ are primary educated and $4 \%$ are are Illiterate. $100 \%$ of study group are feeding industrial, $71 \%$ of them don't receive iron supplement, while $29 \%$ received ion supplement

Fig(1): shows the percentage of study group residence

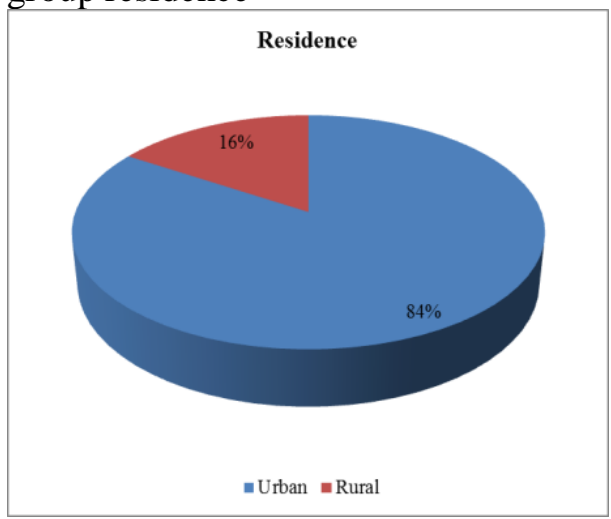

Fig (2) shows the percentage of educational level of the mother

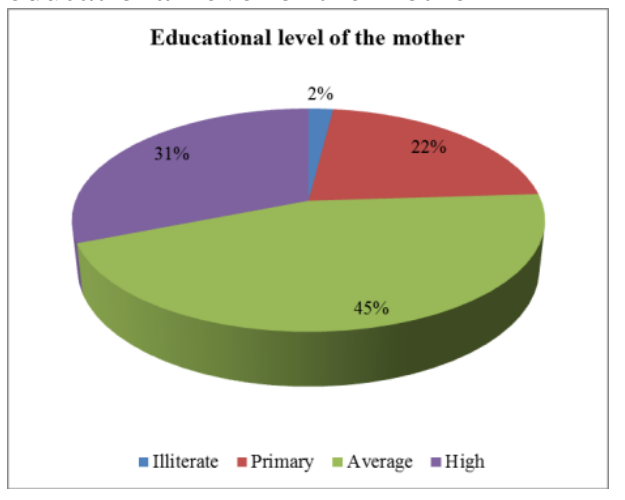

Fig (3): Shows the percentage of educational level of the father

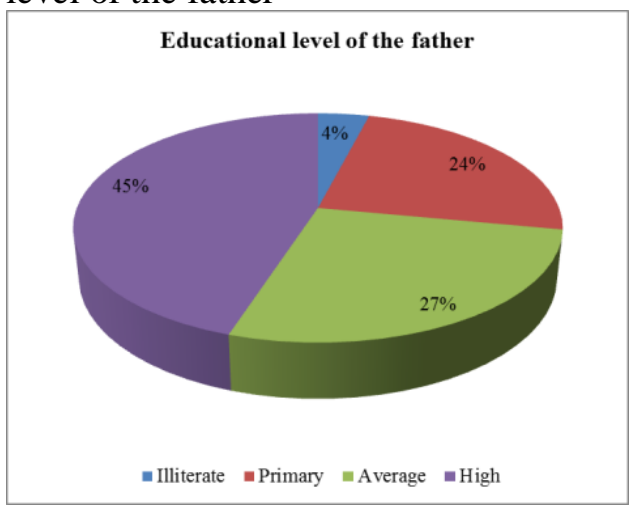

Table (2): Child - specific factors distribution of the study group.

\begin{tabular}{|l|l|l|}
\hline Child-specific factors & No. & $\%$ \\
\hline $\begin{array}{l}\text { Gender } \\
\text { Male }\end{array}$ & 88 & 44 \\
\hline
\end{tabular}




\begin{tabular}{|c|c|c|}
\hline Female & 112 & 56 \\
\hline $\begin{array}{l}\text { Age (months) } \\
\text { 5-12 years }\end{array}$ & 200 & $100 \%$ \\
\hline $\begin{array}{l}\text { Do you suffer from anemia } \\
\text { Yes } \\
\text { No }\end{array}$ & $\begin{array}{l}112 \\
88\end{array}$ & $\begin{array}{l}56 \% \\
44 \% 5\end{array}$ \\
\hline Hemoglobin level (Hb) & \multicolumn{2}{|c|}{$\begin{array}{c}8.5-13.2 \\
{[8.74 \pm 1.97]}\end{array}$} \\
\hline Serum iron $(\mathbf{N} 60-170 \mathrm{mcg} / \mathrm{dL})$ & \multicolumn{2}{|c|}{$\begin{array}{l}43-155 \mathrm{mcg} / \mathrm{dl}) \\
\{17.34 \pm 2.16\}\end{array}$} \\
\hline Transferrin saturation\% & \multicolumn{2}{|c|}{$20.1 \pm 10.2$} \\
\hline $\begin{array}{l}\text { Are you suffering from pallor } \\
\text { conjunctivitis and keeping the hand } \\
\text { or pounding nails } \\
\text { Yes } \\
\text { No }\end{array}$ & $\begin{array}{l}140 \\
60\end{array}$ & $\begin{array}{l}70 \\
30\end{array}$ \\
\hline $\begin{array}{l}\text { Do you suffer from a lack of any of the } \\
\text { other elements (vitamin A or zinc) } \\
\text { No } \\
\text { Vitamin A } \\
\text { Vitamin A \& Zinc }\end{array}$ & $\begin{array}{l}188 \\
4 \\
8\end{array}$ & $\begin{array}{l}94 \\
2 \\
4\end{array}$ \\
\hline $\begin{array}{l}\text { Are you dealing with your child foods } \\
\text { rich in iron } \\
\text { Yes } \\
\text { No }\end{array}$ & $\begin{array}{l}47 \\
153 \\
\end{array}$ & $\begin{array}{l}23.5 \\
\% \\
76.5 \\
\% \\
\end{array}$ \\
\hline Child's height & \multicolumn{2}{|c|}{$\begin{array}{llr}85 & - & 155 \\
{[108.72 \pm 34.13]}\end{array}$} \\
\hline Child's Weight & \multicolumn{2}{|c|}{$\begin{array}{l}10.15-73 \\
{[36.75 \pm 17.98]}\end{array}$} \\
\hline BMI [wt/(ht)^2] & $\begin{array}{l}13.97 \\
{[16.8} \\
\end{array}$ & $\begin{array}{l}30.74 \\
4]\end{array}$ \\
\hline $\begin{array}{l}\text { Are you suffering from any kinds of } \\
\text { worms over the past six months } \\
\text { Yes } \\
\text { No }\end{array}$ & $\begin{array}{l}4 \\
196\end{array}$ & $\begin{array}{l}2 \\
98\end{array}$ \\
\hline $\begin{array}{llll}\text { Are you suffering from chronic } \\
\text { diarrhea } \\
\text { Yes }\end{array}$ & $\begin{array}{l}78 \\
122\end{array}$ & $\begin{array}{l}39 \\
61\end{array}$ \\
\hline $\begin{array}{llll}\text { Do you suffer from poor food } \\
\text { absorption disease } \\
\text { Yes } \\
\text { No }\end{array}$ & $\begin{array}{l}36 \\
164\end{array}$ & $\begin{array}{l}18 \\
82\end{array}$ \\
\hline $\begin{array}{l}\text { Does the child suffering from any } \\
\text { other illnesses } \\
\text { Yes } \\
\text { No }\end{array}$ & $\begin{array}{l}90 \\
110\end{array}$ & $\begin{array}{l}45 \\
55\end{array}$ \\
\hline $\begin{array}{l}\text { What kind of disease, which is } \\
\text { suffering from the child, and whether } \\
\text { any deals with drugs } \\
\text { Yes } \\
\text { No }\end{array}$ & $\begin{array}{l}82 \\
118\end{array}$ & $\begin{array}{l}41 \\
59\end{array}$ \\
\hline
\end{tabular}

Table (2) shows that $56 \%$ of study group is girls and $44 \%$ are boys, $94 \%$ of study group are suffering from anemia and 6\% are healthy.

While $94 \%$ of study group is not suffering from lack of any other elements, $4 \%$ suffering from Vitamin $\mathrm{A}$ and Zinc deficiency and 2\% suffering from vitamin A deficiency, 23.5\% receiving foods rich in iron while $76.5 \%$ aren't receiving foods rich in iron

Fig (4): Shows percentage of other related diseases may cause iron deficiency anemia

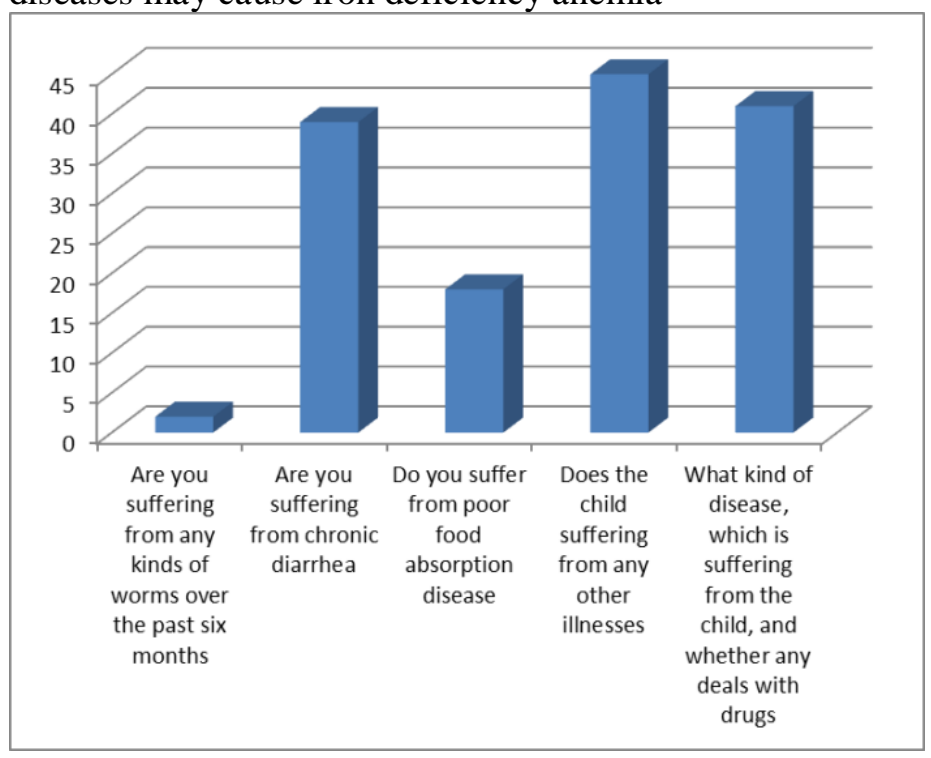

Fig (5): shows the percentage of the study group gender

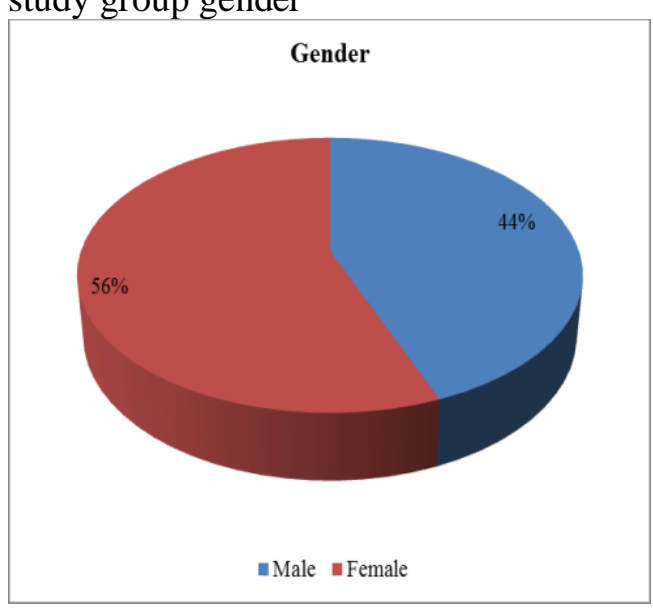

Fig (6): shows the percentage of the incidence of anemia among the study group

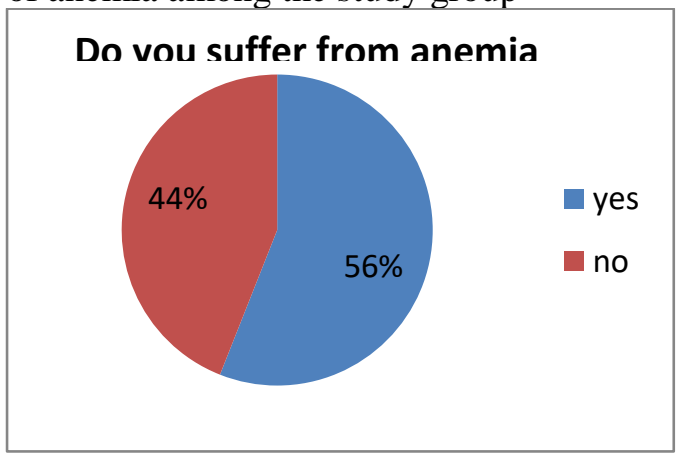

Fig (7) shows the percentage of suffering a lack of any of the other elements (vitamin A or zinc or both) 


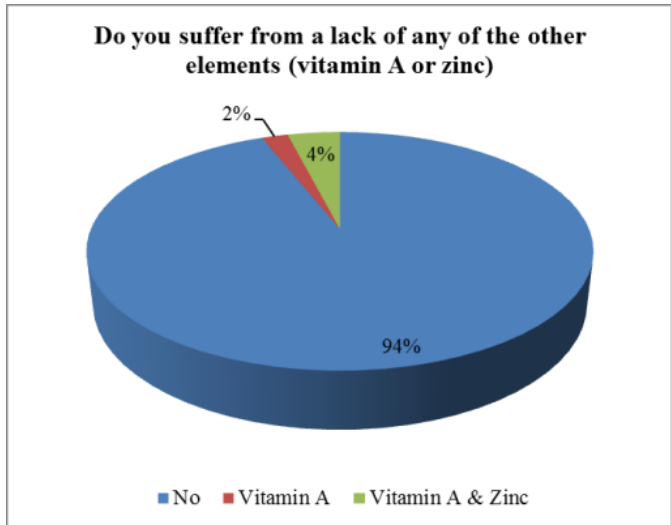

Table (3): Correlation between hemoglobin level and other parameters using Pearson Correlation Coefficient of the study group.

\begin{tabular}{|c|c|c|}
\hline \multirow{2}{*}{ All parameters } & \multicolumn{2}{|c|}{$\begin{array}{l}\text { Hemoglobin } \\
\text { level }\end{array}$} \\
\hline & $\mathbf{R}$ & $\begin{array}{l}\text { p- } \\
\text { value }\end{array}$ \\
\hline Residence & .142 & 0.076 \\
\hline Number of children in the family & $\begin{array}{l}- \\
0.056\end{array}$ & 0.580 \\
\hline Educational level of the mother & $\begin{array}{l}- \\
0.870\end{array}$ & 0.006 \\
\hline Educational level of the father & - & 0.103 \\
\hline Job of father & 0.271 & 0.007 \\
\hline Job of Mother & 0.014 & 0.889 \\
\hline Gender & 0.049 & 0.630 \\
\hline Age (Years) & $-\overline{0}-073$ & 0.474 \\
\hline $\begin{array}{l}\text { Are you suffering from pallor } \\
\text { conjunctivitis and keeping the hand } \\
\text { or pounding nails }\end{array}$ & 0.048 & 0.637 \\
\hline $\begin{array}{l}\text { Do you suffer from a lack of any of } \\
\text { the other elements (vitamin A or } \\
\text { zinc) }\end{array}$ & 0.154 & 0.128 \\
\hline $\begin{array}{l}\text { Are you dealing with your child } \\
\text { foods rich in iron }\end{array}$ & 0.049 & 0.627 \\
\hline Child's height & $\begin{array}{l}- \\
0.067 \\
\end{array}$ & 0.511 \\
\hline Child's Weight & 0.050 & 0.620 \\
\hline $\begin{array}{l}\text { Are you suffering from any kinds of } \\
\text { worms over the past six months }\end{array}$ & $\begin{array}{l}- \\
0.165 \\
\end{array}$ & 0.103 \\
\hline $\begin{array}{l}\text { Are you suffering from chronic } \\
\text { diarrhea }\end{array}$ & 0.072 & 0.480 \\
\hline $\begin{array}{l}\text { Does the child suffering from any } \\
\text { other illnesses }\end{array}$ & 0.001 & 0.994 \\
\hline $\begin{array}{l}\text { What kind of disease, which is } \\
\text { suffering from the child, and } \\
\text { whether any deals with drugs }\end{array}$ & $\begin{array}{l}- \\
0.011\end{array}$ & 0.910 \\
\hline
\end{tabular}

rs: Spearman's rank correlation coefficient; $\mathrm{p}$-value $<0.05$ Significant

Table (3) Shows Positive significant correlation between hemoglobin level with job of father ( $\mathbf{r}$ 0.271, p- value 0.007) and Positive significant correlation between hemoglobin level the
Educational level of the mother $(\mathbf{r}-\mathbf{- 0 . 8 7 0}, \mathbf{p}-$ value 0.006$)$

Table (4): Correlation between hemoglobin level and BMI using Pearson Correlation Coefficient of the study group.

\begin{tabular}{|l|l|l|}
\hline \multirow{2}{*}{ All parameters } & \multicolumn{2}{|l|}{$\begin{array}{l}\text { Hemoglobin } \\
\text { level }\end{array}$} \\
\cline { 2 - 3 } & R & $\begin{array}{l}\text { p- } \\
\text { value }\end{array}$ \\
\hline BMI [wt/(ht) ${ }^{\wedge}$ ] & -0.429 & $\mathbf{0 . 0 1 7}$ \\
\hline $\begin{array}{l}\text { Delayed weaning and No Iron } \\
\text { supplements }\end{array}$ & -0.338 & $\mathbf{0 . 0 2 3}$ \\
\hline Bad food habits & -0.309 & $\mathbf{0 . 0 1 2}$ \\
\hline Warm disease & -0.406 & $\mathbf{0 . 0 2 8}$ \\
\hline $\begin{array}{l}\text { Do you suffer from poor food } \\
\text { absorption disease }\end{array}$ & 0.266 & $\mathbf{0 . 0 3 3}$ \\
\hline Chronic diarrhea & 0.311 & $\mathbf{0 . 0 1 1}$ \\
\hline
\end{tabular}

rs: Spearman's rank correlation coefficient; $p$-value $<0.05$ Significant

Table ( 4 ) shows negative significant correlation and between hemoglobin level with BMI ( $\mathbf{r}$ $0.429 \mathrm{p}$ value 0.017 ) delayed weaning \& no iron supplements ( $\mathrm{r}-0.338 \mathrm{p}$ value $\mathbf{0 . 0 2 3}$ ), bad food habits ( $\mathbf{r}-0.309 \mathrm{p}$ value 0.012$)$ and warm disease, ( $\mathrm{r}-\mathbf{- 0 . 4 0 6} \mathrm{p}$ value $\mathbf{0 . 0 2 8}$ ), suffering from poor food absorption disease $(\mathbf{r}$ 0.266p value $\mathbf{0 . 0 3 3}$ ) and chronic diarrhea ( $\mathbf{r}-\mathbf{- 0 . 3 1 1 p}$ value 0.011 )

Table(5) shows prevalence of anemia among the study group:

\begin{tabular}{|l|l|l|}
\hline Child parameters & No. & $\%$ \\
\hline High BMI & 120 & $60 \%$ \\
\hline High BMI with anemia & 95 & $79.2 \%$ \\
\hline High BMI without anemia & 25 & $20.8 \%$ \\
\hline Nomal BMI & 80 & $40 \%$ \\
\hline normal BMI with anemia & 17 & $21.25 \%$ \\
\hline normal BMI without anemia & 63 & $78.75 \%$ \\
\hline
\end{tabular}

Table (5): shows $60 \%$ of the study group are suffering from high BMI 79.2\% of them suffering from IDA, while $\mathbf{2 0 . 8 \%}$ are healthy. $40 \%$ of study group are with normal BMI $21.25 \%$ of them are suffering from anemia while $63 \%$ are healthy 
Fig 8 shows prevalence of anemia among the study group:

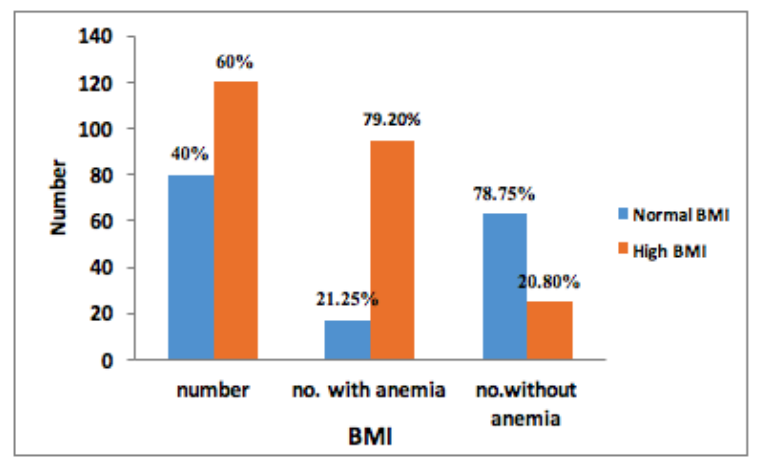

Fig. (8): Scatter plot, Significant Negative correlation between Hemoglobin level and BMI.

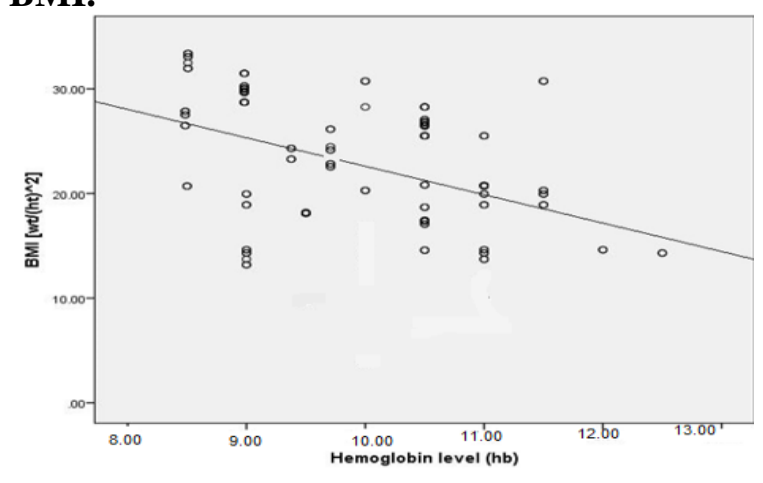

\section{Discussion:}

Many aspects of the physiological regulation of human iron homeostasis have been elucidated over the past decade. It appears counterintuitive that obesity as a condition of calorie and nutrient excess is associated with Iron deficiency anemia . Iron deficiency could represent one of the comorbidities associated with the typical chronic low-grade inflammation state of obese patients. Iron homeostasis is affected by obesity in a many-facetted fashion ${ }^{12}$.

Hypoferremia which is obesity related etiology may be mediated through increased hepcidin expression through inflammatory pathways originating from adipose tissue ${ }^{6}$. Hepcidin which is the main inhibitor of intestinal iron absorption, and Hepcidin promoter level increased in the presence of leptin. Hepcidin expression in adipose tissue may contribute to elevate hepcidin concentration in the obese $\mathrm{o}^{8}$. recent studies suggested that leptin upregulates hepatic hepcidin expression through the JAK2/STAT3 signaling pathway. So, the increased production of leptin in overweight individuals might be a major contributor to the aberrant iron status observed in these population groups ${ }^{9}$.

Hepcidin bind to the iron export channel ferroportion and breaks down the transporter protein in the lysosome. Inhibiting ferroportin prevents iron from being exported and the iron is sequestered in the cells, iron release from macrophages , Also, hepcidin prevents enterocytes from allowing iron into the hepatic portal system, thereby reducing dietary iron absorption ${ }^{11}$.

Studies have correlated obesity, BMI, and increased hepcidin in children, obesity considered as an independent factor contributing to iron deficiency Chronic inflammation has been associated with central obesity and implicated in many obesity-related problems such as insulin resistance ${ }^{13}$.

In the current study, we had observed that there is a positive significant correlation between hemoglobin level with job of father ( $\mathrm{r}$ 0.271, p- value 0.007) as fathers do play an important part in their children's lives; the high standard of life will improve the cognitive, behavioral and general health and well-being areas of a child's life and The quantities of nutrients provided by the diet. Our result was agreed with Lawrence et al 2009 results which showed that children from less well-off father were at greater risk than wealthier children for poor cognitive, behavioral and health outcomes ${ }^{14}$.

In the current study result shows a negative significant correlation between hemoglobin levels with BMI ( $\mathrm{r}-0.429 \mathrm{p}$ value 0.017 ), this correlation is agreed with Ayse Gozkaman et al 2015 results which showed that BMI levels were found to be significantly different in group-1 ( $\mathrm{Hb} \leq 7 \mathrm{~g} / \mathrm{dl})$, group-2 $(7 \mathrm{~g} / \mathrm{dl}<\mathrm{Hb} \leq 10$ $\mathrm{g} / \mathrm{dl})$, group-3 $(10 \mathrm{~g} / \mathrm{dl}<\mathrm{Hb} \leq 12 \mathrm{~g} / \mathrm{dl})$ also negative correlation between BMI and iron binding capacity $(r=-0.223, P=0.011)$. Ayse Gozkaman et al 2015 concluded that both overweight/obesity and central obesity were inversely associated with anemia ${ }^{15}$.

In contrast to the current study, Yuji et al. studies have reported that, High BMI had significantly higher hemoglobin levels than those with a Low BMI. They explained there 
results with that, obese persons exhibit reduced adipose tissue oxygenation which lead to erythropoietin gene transcription stimulating factors, as hypoxia inducible factor-1 (HIF-1), are overexpressed in the adipose tissue of obese subjects. Since hypoxia is known to be a stimulator of hemoglobin production and erythropoietin is known to be a stimulator of hemoglobin synthesis, the BMI may well be associated with the hemoglobin levels ${ }^{16}$.

Our study also showed that there had been a negative significant correlation between BMI and serum iron levels; which is consistent with the study of Baumgartner et al . in which they had reported that lower iron levels in individuals with high BMI. The significant relationship between obesity and iron deficiency anemia can be attributed Baumgartner et al to a combination of nutritional and functional parameters as well as genetic influence, lack of physical activity, and an increase in hepcidin concentration, reduce in iron intake, increase in needs for iron and disorder in iron absorption in obese subjects and break less myoglobin and subsequently a decrease in the release of iron in the blood, poor diet and less iron-rich foods ${ }^{17}$.

Zimmermann et al . study among the Thai women showed a higher BMI Z-score associated with decreased iron absorption $(\mathrm{P}=0.030)$. In the Indian and Moroccan children, a higher BMI Z-score predicted poorer iron status at baseline $(\mathrm{P}<0.001)$ and less improvement in iron status during the interventions $(\mathrm{P}<0.001)$. Zimmermann et al Conclusion is agreed with this current study that Adiposity in young women predicts lower iron absorption, and pediatric adiposity predicts iron deficiency and also a reduced response to iron fortification ${ }^{18}$.

In contrast to the results of our study, Akram et al . result showed that BMI had no correlation with hemoglobin, MCV, Serum Iron, and ferritin, he explained that IDA in obese patient may be attributed to an unbalanced diet which lead to low iron intake, reduced iron absorption in small intestine, greater iron requirement caused by a large blood volume another. Another cause of Akram Ghadiri et al finding may be well nutritional status of obese people as intake of high iron foods ${ }^{19}$.
Abeer et al had reported that the group of obese children had significantly lower serum iron than non obese children group which is agreed with the results of the current study. On the other hand Abeer A et al reported that there was significant increase in body weight, as well as the levels of serum Hepcidin, and plasma Leptin $(\mathrm{P}<0.05)$ in obese group when compared to non-obese group. The most plausible explanation for the link between poor iron status and obesity is the significant increase in Hepcidin in obese animals, as evidenced by the significant direct correlation between serum Hepcidin and body weight and the statistically significant inverse correlations which was found between serum Hepcidin and serum iron $(\mathrm{r}=-0.980 ; \mathrm{P}=0.0001)^{10}$.

Significant negative correlation was observed in the current study between TS and children with high body mass index. A similar correlation was found among 5-12-year-old Mexican children with high body mass index with lower TS percentage $(r=-0.07, p=0.07)$ than the normal-weight group ${ }^{10}$.

The prevalence of obesity is rising in developed and developing nations ${ }^{6}$. Current study showed increased prevalence of high BMI $(60 \%)$ as compared to normal BMI (40\%) among the study group which is explained by the new diets which have been replacing traditional diets rapidly, these new diets contain large amounts of fat, sugar, oil, environmental factors such as marketing, advertising, increasing portion sizes, accessibility and availability of calorie dense foods and increased automation, all increased energy intake and decreased energy expenditure which can lead to obesity among children and adolescents ${ }^{4}$.

Anemia among school-aged children is known to be a significant global public health problem affecting 305 million people around the world. In developing countries. its prevalence ranges from $29.2 \%$ to $79.6 \%{ }^{20}$. Even in USA as many as $20 \%$ of children are assumed to become anemic at some point by the age of 18 years Iron deficiency anemia appears to be prevalent among Saudi Arabia school students, at age 12 years and over, low social class and menstruating girls constitute the highrisk groups ${ }^{21}$. The prevalence of anemia of school girls aged 7-14 years old in Riyadh city was $(22.2 \%)$, while it was $26.4 \%$ in primary school girls of urban area of Al-Khober 
in the Eastern province of Saudi Arabia ${ }^{7}$. In developing countries its prevalence ranges from $29.2 \%$ to $79.6 \%$. $^{2}$

Similar to results of our study, a study conducted in the United States by Nead et al 2004 on 2 - 16 years old children, the prevalence of ID and IDA in overweight or at risk of overweight was two times higher than normal weight children, also they reported that the prevalence of iron deficiency increased as BMI increased from normal weight to at risk for overweight to overweight $(2.1 \%, 5.3 \%$, and $5.5 \%$, respectively), and iron deficiency was particularly common among adolescents $(3.5 \%$, $7.2 \%$, and $9.1 \%$, respectively). In a multivariate regression analysis, children who were at risk for overweight and children who were overweight were approximately twice as likely to be iron-deficient ${ }^{22}$

In contrast, Keikhaei et al. in their study did not find a clear difference in serum iron levels with different levels of BMI among boys and girls, explained by Multiple different factors such as genetics, faster growth, physical inactivity, inadequate iron -rich diet and decrease in myoglobin iron recycling may be involved ${ }^{23}$. Mei et al . showed that the absorption of radiolabeled iron in obese mouse models was 2 to 2.5 times more than lean mice. Despite this increased absorption, the concentrations of iron in the obese mice tissues were significantly lower than lean mice. Mei et al.concluded that variations in the tissue distribution and metabolism of iron lead to changes in tissue concentrations of trace metals in obese mice ${ }^{24}$.

\section{Conclusion:}

Hepcidin plays a central role in the anemia of chronic disease and Hepcidin overproduction even in mild inflammatory disorder as obesity may explain the association of poor iron status with obesity. IL6 and Leptin may be part of the axis that links obesity, inflammation, and Hepcidin with poor iron status.

This study suggests that the higher levels of total and central obesity should be taken into account when assessing the children's body iron status and should be treated before providing dietary recommendations to correct anemia.
1. Gahagan S (2011): Overweight and obesity. In: Nelson text book of pediatrics, 19th ed. Philadelphia: Elsevier Saunders.

2. Abdellal M, le Roux CW, Docherty NG (2017): Morbidity and mortality associated with obesity. Ann Transl Med., 5(7): 161.

3. World Health Organization (2014): Global status report on non-communicable diseases Available at: http://apps.who.int/iris/bitstream/10665/14 8114/1/9789241564854_eng.pdf.

4. Kranz S, Smiciklas-Wright H, Siega-Riz AM, Mitchell D (2005): Adverse effect of high added sugar consumption on dietary intake in American preschoolers. J Pediatr., 146(1): 105-111.

5. Daniels SR, Arnett DK, Eckel RH, Gidding SS, Hayman LL, Kumanyika S, Robinson TN, Scott BJ, St Jeor S, Williams CL (2005): Overweight in children and adolescents: pathophysiology, consequences, prevention and treatment. Circulation, 111(15): 1999-2012.

6. Khatib IM, Elmadfa I (2009): Poor nutritional health of Bedouin preschool children in Jordon: the irony of urbanization. Ann Nutr Metab.,54(4):301309.

7. M Alqarni SS (2016): Review of Prevalence of Obesity in Saudi Arabia. J Obes Eat Disord., 2(2): 25.

8. Richardson MW, Ang L, Visintainer PF, Wittcopp CA (2009): The abnormal measures of iron homeostasis in pediatric obesity are associated with the inflammation of obesity. Int $\mathbf{J}$ Pediatr Endocrinol., 2009: 713269.

9. Coelho M, Oliveira T, Fernandes $\mathbf{R}$ (2013): Biochemistry of adipose tissue: an endocrine organ. Arch Med Sci., 9(2): 191200.

10. Abo Zeid AA, El Saka MH, Abdalfattah AA, Zineldeen DH (2014): Potential factors contributing to poor iron status with obesity. Alexandria J Med., 50(1): 45-48.

11. World Health Organization (2001): Iron Deficiency Anaemia: Assessment, Prevention and Control. A Guide for Programme Managers, Available at: http://www.who.int/nutrition/publications/ en/ida assessment prevention control.pdf

\section{References:}


12. al-Othaimeen A, Osman AK, al Orf $S$ (1999): Prevalence of nutritional anaemia among primary school girls in Riyadh City, Saudi Arabia. Int J Food Sci Nutr., 50(4): 237-243.

13. Hintze KJ, McClung JP (2011): Hepcidin: A Critical Regulator of Iron Metabolism during Hypoxia. Adv Hematol., 2011: 510304.

14. Berger LM, Paxson C, Waldfogel J (2009): Income and Child Development. Child Youth Serv Rev., 31(9): 978-989.

15. Gozkaman A, Okuturlar Y, Mert M, Harmankaya O, Kumbasar A (2015): The relationship between haemoglobin and BMI in overweight and obese patients. DOI: 10.1530/endoabs.37.EP632.

16. Shimizu $Y$, Nakazato $M$, Sekita $T$, Kadota K, Arima K, Yamasaki H, Takamura N, Aoyagi K, Maeda T (2014): Association between the Hemoglobin Levels and Hypertension in Relation to the BMI Status in a Rural Japanese Population: The Nagasaki Islands Study. Intern Med., 53(5): 435440.

17. Baumgartner J, Smuts CM, Aeberli I, Malal L, TjalsmaH, Zimmermann MB (2013): Overweight impairs efficacy of iron supplementation in iron deficient South African children: a randomized controlled intervention. Int $\mathrm{J}$ Obes (Lond.), 37(1): 24-30.

18. Zimmermann MB, Zeder C, Muthayya S, Winichagoon P, Chaouki N, Aeberli I, Hurrell RF (2008): Adiposity in women and children from transition countries predicts decreased iron absorption, iron deficiency and a reduced response to iron fortification. Int $\mathbf{J}$ Obes (Lond.), 32(7): 1098-1104.
19. Ghadiri-Anari A, Nazemian N, Vahedian-Ardakani HA (2014): Association of body mass index with hemoglobin concentration and Iron parameters in Iranian Population. ISRN Hematology.http://dx.doi.org/10.1155/20 14/525312.

20. Chung B, Matak P, McKie AT, Sharp P (2007): Leptin increases the expression of the iron regulatory hormone hepcidin in HuH7 human hepatoma cells. J Nutr., 137 (11): 2366-2370.

21. Gad A, Al-Quaiz J, Khoja T, As-Sharif A, Al-Manea H, Al-Edriss A, Shafi S (2012): Anemia among Primary School Children (5 -12 years) in Riyadh Region, Saudi Arabia: A Community-Based Study. Canadian J Clin Nutr., 1(1): 27-34.

22. Nead KG, Halterman JS, Kaczorowski JM, Auinger P, Weitzman M (2004): Overweight children and adolescents: a risk group for iron deficiency. Pediatrics, 114(1): 104-8.

23. Keikhaei B, Askari R, Aminzadeh M (2012): Adolescent with Unfeasible Body Mass Index: A Risk Factor for Iron Deficiency Anemia. J Health Med Informat., Available at: http://www.omicsonline.org/adolescentwi th-unfeasible-body-mass-index-a-riskfactor-foriron-deficiency-anemia-21577420.1000109.pdf.

24. Mei Z, Cogswell ME, Looker AC, Pfeiffer CM, Cusick SE, Lacher DA, Grummer-Strawn LM (2011): Assessment of iron status in us pregnant women from the national health and nutrition examination survey (NHANES), 1999-2006. Am J Clin Nutr., 93 (6): 13121320. 